\title{
EFEK VARIASI BEBAN PENDINGINAN TERHADAP COEFFICIENT OF PERFORMANCE (COP) MESIN PENDINGIN PADA BOX COOLER ALAT DISTILASI
}

Ahmad Akromul Huda ${ }^{*}$, Karyanik ${ }^{1}$, Earlyna Sinthia Dewi ${ }^{1}$

${ }^{1}$ Program Studi Teknik Pertanian, Universitas Muhammadiyah Mataram, Indonesia *Co-author: akromul.huda@ummat.ac.id

\begin{abstract}
Article Information
History:

Received: 27-09-2021

Accepted: 31-10-2021

\section{Keywords:}

Box cooler

Coefficient of

Performance

Cooling engine

performance

Distillation

Refrigerator

ABSTRACT

Abstrak: Mesin pendingin sudah sangat banyak digunakan oleh masyarakat dan dapat dijumpai pada hampir setiap pertokoan, gedung-gedung kantor dan rumah tangga. Pengaplikasian mesin pendingin juga dapat dikembangkan dalam banyak peralatan dan mesin lainnya salah satunya pada alat distilasi. Distilasi atau penyulingan merupakan salah satu cara pemisahan diantara dua zat. Mesin distilasi dengan menggunakan mesin pendingin pada kondensor akan sangat membantu terutama untuk penyulingan. Penelitian ini bertujuan untuk mengetahui efek beban pendingin terhadap kinerja mesin pendingin. Kinerja mesin pendingin meliputi koefisien prestasi (COP). Variasi beban pendinginan dilakukan dengan mengatur temperatur boiler menggunakan thermostat. Pada penelitian ini diambil data temperatur dan tekanan refrigeran yang mengalir dalam sistem mesin pendingin yang terletak pada empat titik yaitu sebelum memasuki kompresor, sebelum memasuki kondensor, sebelum memasuki pipa kapiler dan sebelum memasuki evaporator . Pada penelitian ini juga digunakan empat variasi beban pendinginan yang diberikan pada box cooler sebesar $110^{\circ} \mathrm{C}, 125^{\circ} \mathrm{C}, 140{ }^{\circ} \mathrm{C}$, dan $155^{\circ} \mathrm{C}$. Kemudian data temperatur dan tekanan diolah untuk mendapatkan nilai COP setiap waktu dari semua variasi beban pendinginan. Hasil penelitian menunjukkan bahwa semakin tinggi beban pendinginan maka semakin kecil nilai COP mesin pendingin. Dalam pengaruhnya terhadap lama waktu pengujian nilai COP setiap variasi beban pendinginan cenderung semakin bertambah. Nilai COP tertinggi pada penelitian ini didapatkan pada temperatur beban pendinginan $110{ }^{\circ} \mathrm{C}$ sebesar 10,69 dan terendah didapatkan pada temperatur $155^{\circ} \mathrm{C}$ sebesar 9,38 .
\end{abstract}

\begin{abstract}
Refrigerator has been widely used by the community and can be found in almost every shop, office building and household. The application of refrigeration machines can also be developed in many other equipment and machines, one of which is in the distillation apparatus. Distillation is a method of separating two substances. A distillation machine using a cooling machine in the condenser will be very helpful, especially for distillation. This study aims to determine the effect of cooling on the performance of the cooling machine. Cooling engine performance coefficient of achievement (COP). Load variations are carried out by adjusting the boiler temperature using a thermostat. In this study, data on the temperature and pressure of the refrigerant flowing in the refrigeration system were taken at four points, namely before entering the compressor, before entering the capillary tube and before entering the evaporator. In this study also used four variations of the cooling load given to the box cooler of $110^{\circ} \mathrm{C}, 125^{\circ} \mathrm{C}, 140{ }^{\circ} \mathrm{C}$, and $155^{\circ} \mathrm{C}$. Then the temperature and pressure data is processed to get the COP value every time from all variations of the cooling load. The results showed that the increaseing in the cooling load, the smaller the COP value of the cooling machine. In its effect on the length of time the COP value of each variation of the cooling load increases. The highest COP value in this study was obtained at a cooling load temperature of $110^{\circ} \mathrm{C}$ of 10.69 and the lowest was obtained at a temperature of $155^{\circ} \mathrm{C}$ of 9.38 .
\end{abstract}

\section{A. LATAR BELAKANG}

Mesin pendingin merupakan sebuah alat yang digunakan untuk mengambil kalor dari tempat yang bersuhu rendah dan membuang kalor tersebut ke tempat yang bersuhu tinggi. Pada saat ini mesin pendingin sudah sangat banyak digunakan oleh masyarakat khususnya diperkotaan, mesin pendingin dapat dijumpai pada hampir setiap pertokoan, gedung gedung kantor dan rumah tangga. Mesin pendingin sendiri dapat berupa refrigerator, freezer, chiller serta $\mathrm{AC}$ (air conditioning). AC sendiri fungsinya adalah sebagai pendingin atau penyejuk temperatur udara yang ada dalam ruangan (Anwar 2010).
Dalam dunia industri penggunaan mesin pendingin yang paling umum yaitu untuk proses produksi seperti pengkondisian ruangan dan pengawetan bahan makanan atau minuman (Metty, Negara, and Wijaksana 2012). Selain sebagai pengawet bahan makanan mesin pendingin dapat diaplikasikan langsung sebagai komponen penunjang suatu alat atau mesin contohnya pada kendaraan yang menggunakan $\mathrm{AC}$ agar temperatur dalam kendaraan menjadi sejuk. Pengaplikasian mesin pendingin juga dapat dikembangkan dalam banyak peralatan dan mesin lainnya salah satunya pada alat distilasi .

Distilasi atau penyulingan merupakan salah satu cara pemisahan diantara dua zat. Pemisahan dua zat yang 
dimaksud dalam hal ini adalah zat cair dari campurannya yang merupakan akibat dari perbedaan titik didih yang dimiliki atau dengan kata lain akibat perbedaan kemampuan zat untuk menguap. Prinsip distilasi dapat digambarkan sebagai proses suatu campuran yang dipanaskan hingga titik didihnya kemudian menjadi uap yang dialirkan ke dalam alat pendingin (kondensor) dan dikumpulkan hasil pengembunan dari alat pendingin sebagai zat cair (Mursito, Sukadana, and Tenaya 2017).

Langkah distilasi atau penyulingan dimulai dari bahan bahan baku hasil fermentasi antau jenis lainnya dimasukkan ke dalam tungku yang tertutup rapat kemudian dipanaskan hingga mencapai titik didihnya. Saat bahan campuran meningkat temperaturnya maka bahan yang memiliki titik didih yang rendah akan menguap terlebih dahulu misalkan etanol atau air. Uap yang dihasilkan dari pemanasan tersebut selanjutnya dialirkan menuju bagian kondensor untuk dikondensasikan menjadi bentuk cair. Bagian dalam kondensor tersebut dapat berupa lilitan pipa yang dialiri cairan pendingin sehingga uap panas bisa terkondensasi (Rubianto, Winarso, and Wibowo 2018).

Penggunaan cairan pendingin sebagai penyerap kalor pada kondensor memiliki kelemahan terutama karena jumlah air dingin yang harus disediakan lumayan banyak sehingga mengharuskan menyediakan tempat sebagai wadah penampung air untuk di sirkulasikan ke kondensor. Selain dari pada itu untuk mendinginkan air sirkulasi tersebut juga harus menambahkan es batu ke dalam wadah penamapung air. Maka dari itu dibutuhkan suatu box cooler yang menjadi wadah untuk terjadinya perpindahan panas dari uap yang mengalir kepada air dingin (Mainil and Aziz 2015). Penggunaan box cooler sebagai kondensor akan lebih efisien sehingga uap panas dari bahan campuran dapat langsung didinginkan.

Box cooler terdiri dari kondensor alat distilasi yang dibenamkan ke dalam wadah berisi air yang didinginkan oleh evaporator mesin pendingin. Mesin pendingin yang digunakan adalah mesin pendingin yang memiliki spesifikasi yang sama dengan lemari es ukuran kecil. Dengan adanya mesin pendingin tersebut akan membuat air yang dilewati oleh uap dari tungku pemanas yang melalui kondensor dapat terserap temperaturnya sehingga menjadi cair. Sedangkan air yang ada di dalam box cooler digunakan untuk menyimpan temperatur dingin lebih lama. Air

Mesin distilasi dengan menggunakan mesin pendingin pada kondensor akan sangat membantu terutama untuk penyulingan bioetanol atau biodiesel yang menjadi energi terbarukan pengganti BBM yang selama ini konsumsinya terus meningkat. Konsumsi energi di Indonesia terus meningkat rata-rata sebesar 2,9\% per tahun pada periode 2000-2012. Jenis energi yang paling dominan digunakan adalah bahan bakar minyak (BBM) yang meliputi avtur, avgas, bensin, minyak tanah, minyak solar, minyak diesel, dan minyak bakar. Sektor transportasi merupakan sektor yang paling besar dalam menggunakan BBM (BPPT 2014). Semakin meningkatnya konsumsi energi yang terus menerus mengakibatkan ketersediaan energi dari bahan bakar fosil yang tidak dapat diperbarui semakin berkurang (Emmaputri et al. 2019).

Bioetanol adalah zat yang merupakan hasil proses fermentasi gula dari sumber karbohidrat (pati) menggunakan bantuan mikroorganisme. Produksi bioetanol dari tanaman yang mengandung pati atau karbohidrat, dilakukan melalui proses konversi karbohidrat menjadi gula atau glukosa. Glukosa tersebut kemudian difermentasi dengan cara menambahkan yeast atau ragi sehingga diperoleh bioetanol (Seftian, Antonius, and Faizal 2012). Bietanol yang diperoleh pada akhir proses fermentasi masih berupa campuran antara air dengan etanol. Campuran larutan tersebut dapat dipisahkan dengan cara distilasi, karena distilasi mampu memisahkan dua atau lebih komponen cairan berdasarkan perbedaan titik didihnya (Marjoni 2014).

Sistem pendingin yang terpasang pada box cooler alat distilasi harus mempunyai kapasitas pendinginan yang tepat dan mampu untuk dikendalikan dalam pengoperasiannya. Kapasitas pendinginan peralatan tersebut dapat diketahui berdasarkan beban pendinginan yang senantiasa dapat berubah-ubah (Santosa et al. 2017). Beban pendinginan sendiri sebenarnya merupakan jumlah panas yang mampu dipindahkan oleh sistem pendingin setiap waktu (Siagian 2017).

Beban pendinginan merupakan kalor atau tambahan kalor yang berasal dari suatu ruang. Tambahan panas adalah jumlah panas yang masuk kedalam ruang melalui kaca secara radiasi ataupun melalui dinding akibat perbedaan temperatur, pengaruh penyimpanan energi pada struktur bangunan, serta peralatan peralatan listrik seperti lampu dan peralatan elektronik lainnya setiap saat (Ilminnafik and Listyadi 2013).

Pada penelitian ini beban pendinginan diperoleh dari uap panas tungku pemanas. Pada tungku pemanas bahan hasil fermentasi yang akan didistilasi di panaskan sehingga yang memiliki batas penguapan rendah akan menguap. Temperatur uap panas dari tungku menjadi beban pendingin ini secara langsung akan berdampak pada kinerja mesin pendingin dikerenakan berkaitan dengan perubahan kondisi khususnya temperatur refrigeran pada setiap titik di dalam suatu sistem mesin pendingin.

Penelitian ini bertujuan untuk mengetahui efek beban pendingin terhadap kinerja mesin pendingin. Kinerja mesin pendingin meliputi koefisien prestasi (COP). Sehingga penggunaan mesin pendingin dapat lebih efektif dan efisien. 


\section{B. METODE PENELITIAN}

Penelitian ini berfokus pada performa mesin pendingin sehingga hasil proses distilasi hasil fermentasi buah duku yaitu cairan alkohol tidak di tampilkan. Metode penelitian yang digunakan adalah metode eksperimental, dimana mesin distilasi di uji coba langsung dengan pengukuran temperatur dan tekanan pada titik yang telah ditentukan pada mesin pendingin. Titik yang menjadi titik pengukuran dapat dilihat pada Gambar 1 yang mana merupakan gambar skema mesin pendingin.

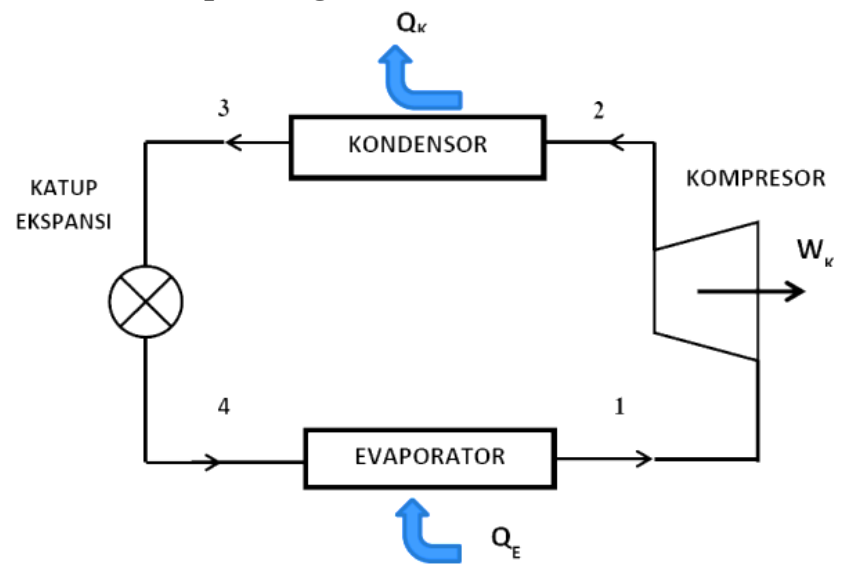

Gambar 1. Diagram Proses Siklus Kompresi Uap: 1. Titik Sebelum masuk kompresor; 2. Titik sebelum masuk kondensor; 3. Titik sebelum masuk katup ekspansi; 4. Titik sebelum masuk evaporator

Pengukuran tekanan dan temperatur yang dilakukan dikhususkan pada mesin pendingin yang digunakan sebagai media pendingin mesin distilasi. Pengukuran tekanan dan temperatur bertujuan untuk mengetahui nilai entalphi sistem pendingin sehingga dapat diketahui efektifitas mesin pendingin (COP). Penghitungan nilai entalphi dengan mengambil hubungan antara temperatur dan tekanan pada setiap titik menggunakan diagram Psicometry Chart sehingga dapat digambarkan siklus yang terjadi pada setiap pengambilan data seperti Gambar 2 (Ramadan, 2018).

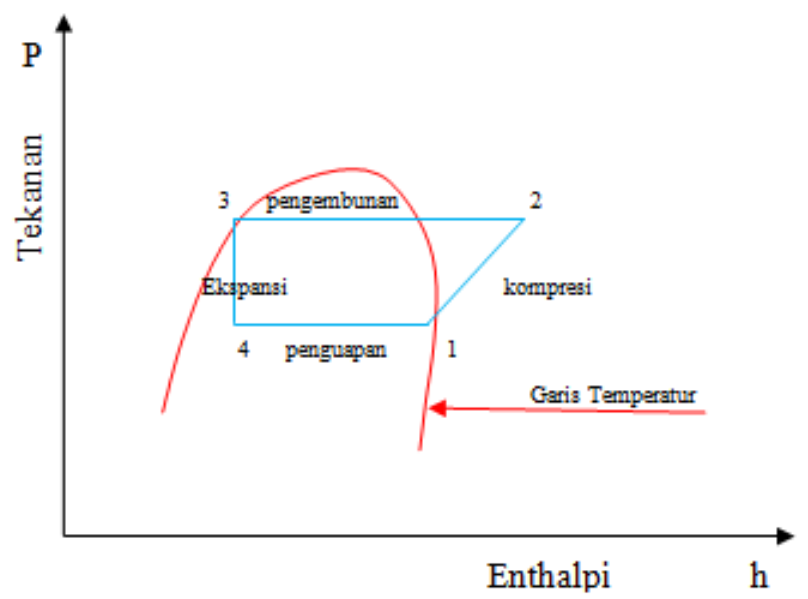

Gambar 2. Siklus Kompresi Uap Standar dalam Diagram Tekanan (P) - Entalphi (h)
Hubungan Beban Pendinginan dan COP adalah fungsi yang kuat dari laju perpindahan termal dari Ruangan panas yang merupakan efektifitas pertukaran panas sisi panas dan dingin(Chen, Wu, and Sun 1998)

Pada penelitian ini juga digunakan empat variasi beban pendinginan yang diberikan pada box cooler sebesar $110^{\circ} \mathrm{C}, 125^{\circ} \mathrm{C}, 140^{\circ} \mathrm{C}$, dan $155^{\circ} \mathrm{C}$. Variasi beban pendingin terbut dilakukan dengan mengatur temperatur tungku pemanas cairan hasil permentasi untuk didistilasi menggunakan Thermostat. Sehingga dengan adanya beban pendinginan maka mesin pendingin bertugas untuk mendinginkan temperatur yang memasuki box cooler.

Setelah data temperatur dan tekanan diperoleh maka dapat ditentukan kondisi refrigeran setiap titik pada siklus menggunakan Psicometry Chart. Psicometri chart akan menampilkan nilai entalphi proses yang terjadi baik saat panas diserap atau dilepaskan, yang menyebabkan perbedaan suhu di di dalam box cooler yang bertemu komponen sistem sehingga semua nilai entaphi yang mempresentasikan kondisi refrigeran saat proses dapat ditampilkan (Nikhil Babu et al. 2021).

Berdasarkan kondisi refrigeran atau entalphi yang telah diketahui maka dapat dihitung prestasi mesin pendingin (COP) untuk setiap variasi beban pendingin. Dengan menggunakan rumus sebagai berikut:

- COP (Coefisient Of Performance)

$\mathrm{COP}=\frac{h_{1}-h_{4}}{h_{2}-h_{1}}$ atau $\mathrm{COP}=\frac{Q_{\text {evap }}}{W_{k}}$

$$
\begin{array}{ll}
\text { Dimana: } & h_{1}=\text { entalphi sebelum masuk kompresor }\left(\frac{k j}{k g}\right) \\
& h_{2}=\text { entalphi sebelum masuk kondensor }\left(\frac{k j}{k g}\right) \\
& h_{3}= \\
& \text { entalphi sebelum masuk katupekspansi }\left(\frac{k j}{k g}\right) \\
& h_{4}=\text { entalphi sebelum masuk evaporator }\left(\frac{k j}{k g}\right) \\
& Q_{\text {evap }}=\text { efek refrigerasi }\left(\frac{k j}{k g}\right) \\
& W_{k}=\text { Kerja Kompressor }\left(\frac{k j}{k g}\right)
\end{array}
$$

Mesin distilasi yang digunakan pada penelitian ini adalah mesin distilasi dengan media pendingin sistem kompresi uap seperti yang ditampilkan pada Gambar 3. 


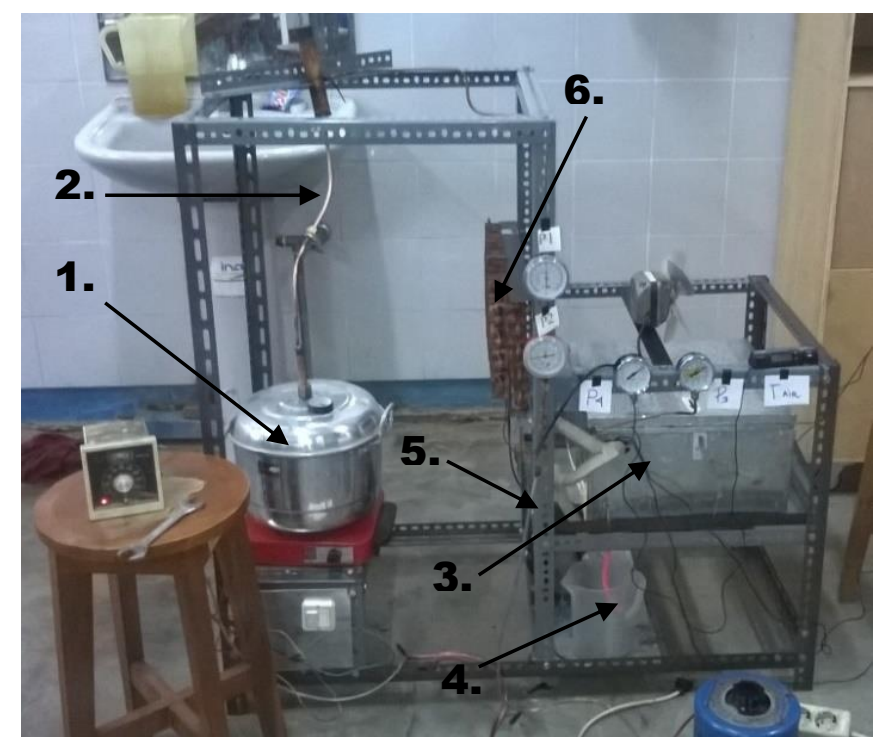

Gambar 3. Mesin Distilasi :1. Tungku Pemanas ; 2. Pipa Saluran Uap; 3. Box cooler; 4. Penampung kondensat; 5. Kompresor Mesin Pendingin; 6. Kondensor Mesin Pendingin

Pada Gambar 3 dapat dilihat box cooler menjadi wadah sebagai tempat terjadinya perpindahan panas antara uap panas tungku uap dengan air dingin yang disebabkan proses refrigerasi oleh evaporator mesin kompresi uap. Untuk lebih jelasnya bisa melihat desain box cooler yang digunakan pada Gambar 4 berikut.

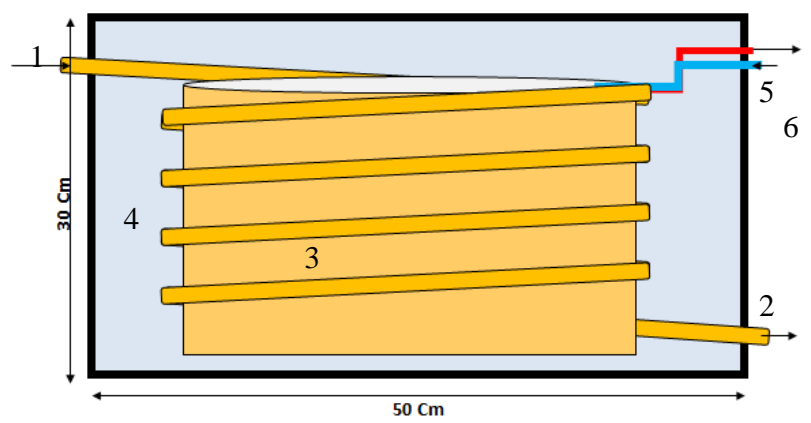

Gambar 4. Box Cooler Mesin Distilasi: 1. Pipa saluran masuk (uap); 2 Pipa saluran keluar (kondensat); $3 . \quad$ Plat penampung air pendingin; 4. Sterofoam box; 5. Saluran masuk refrigeran (evaporator); dan 6. Saluran keluar refrigeran (evaporator)

Pada Gambar 4 menunjukkan bentuk skema boox cooler yang digunakan. Dimensi box cooler ialah berbentuk persegi dengan panjang dan lebar sebesar 50 cm sedangkan tingginya $30 \mathrm{~cm}$. Pipa tembaga dan juga plat tembaga digunakan sebagai pipa dan juga sebagai wadah penampung air yang akan didinginkan. Penggunaan bahan tembaga adalah agar proses perpindahan panas yang dibawa uap dari tungku pemanas dapat terjadi lebih cepat sehingga kondensat yang dihasilkan lebih banyak.

Box cooler dibuat dengan menggunakan pipa dan pelat tembaga seperti yang ditunjukkan Gambar 5. Pada bagian dalam wadah tembaga ditempelkan evaporator mesin pendingin sedangkan pada bagian luar ditempelkan pipa saluran uap dari tungku pemanas.
Sterofoam digunakan untuk membungkus box cooler sehingga temperatur didalam box cooler dapat dijaga dan tidak terpengaruh temperatur lingkungan.

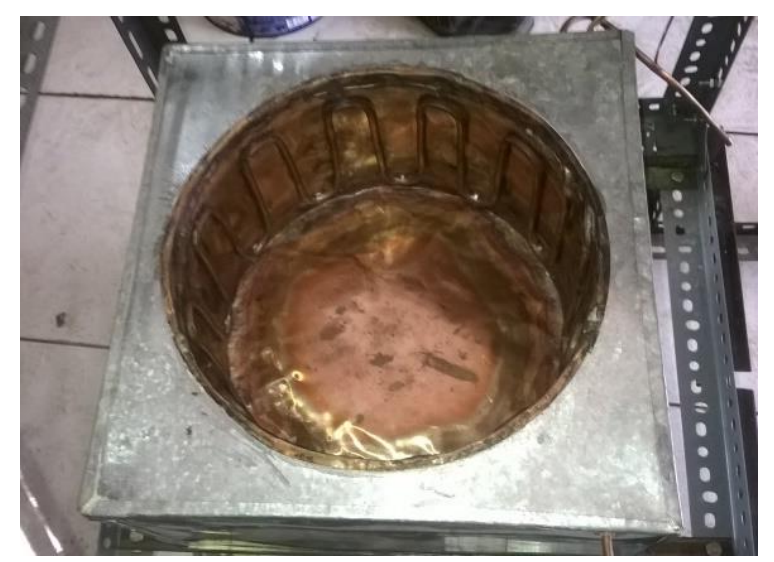

(a)

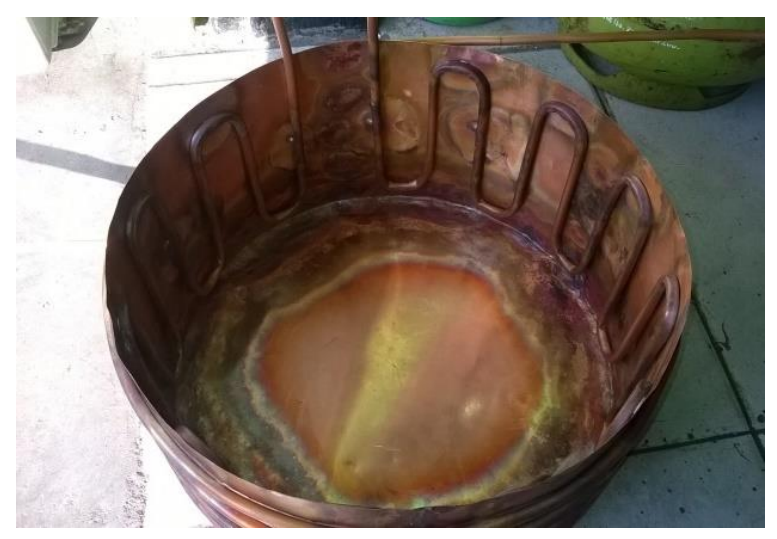

(b)

Gambar 5. Tampilan Box cooler: (a) dengan menggunakan sterofoam; (b) tanpa sterofoam

\section{HASIL DAN PEMBAHASAN}

Data yang diperoleh pada pengujian ini ditampilkan dalam Tabel 1 sampai Tabel 3 .

Tabel 1.

Tekanan dan Temperatur pada Beban Tungku Pemanas 110 ${ }^{\circ} \mathrm{C}$

\begin{tabular}{cccccccc}
\hline $\begin{array}{c}\text { Waktu } \\
\text { (menit) }\end{array}$ & $\begin{array}{c}h_{1} \\
(\mathrm{kj} / \mathrm{kg})\end{array}$ & $\begin{array}{c}h_{2} \\
(\mathrm{kj} / \mathrm{kg})\end{array}$ & $\begin{array}{c}h_{3} \\
(\mathrm{kj} / \mathrm{kg})\end{array}$ & $\begin{array}{c}h_{4} \\
(\mathrm{kj} / \mathrm{kg})\end{array}$ & $\begin{array}{c}q_{\text {evap }} \\
(\mathrm{kj} / \mathrm{kg})\end{array}$ & $\begin{array}{c}W_{k} \\
(\mathrm{kj} / \mathrm{kg})\end{array}$ & COP \\
\hline 10 & 420 & 438,8 & 240,5 & 240,5 & 179,5 & 18,8 & 9,54 \\
20 & 420 & 438,5 & 240,5 & 240,5 & 179,5 & 18,5 & 9,7 \\
30 & 420 & 438,5 & 240,5 & 240,5 & 179.5 & 18,5 & 9,7 \\
40 & 420 & 437.5 & 240,5 & 240,5 & 179,5 & 17,5 & 10,25 \\
50 & 420,2 & 436,6 & 240,5 & 240,5 & 179.6 & 16.4 & 10.95 \\
60 & 420,2 & 436,6 & 240,5 & 240,5 & 179.7 & 16.4 & 10.95 \\
70 & 420,2 & 436,6 & 240,5 & 240,5 & 179.7 & 16.4 & 10.95 \\
80 & 420,2 & 436,2 & 240,5 & 240,5 & 179.7 & 16 & 11.23 \\
90 & 420,2 & 436,2 & 240,5 & 240,5 & 179.7 & 16 & 11.23 \\
100 & 420,2 & 436,2 & 240,2 & 240,2 & 180 & 16 & 11.25 \\
110 & 420,2 & 436,2 & 240,2 & 240,2 & 180 & 16 & 11.25 \\
120 & 420,2 & 436,2 & 240,2 & 240,2 & 180 & 16 & 11.25 \\
\hline \multicolumn{7}{c}{ Jumlah Total : } \\
\hline \multicolumn{7}{c}{ Rata - rata : }
\end{tabular}


Tabel 2.

Tekanan dan Temperatur pada Beban Tungku Pemanas $125^{\circ} \mathrm{C}$

\begin{tabular}{llllllll}
\hline $\begin{array}{l}\text { Waktu } \\
\text { (menit) }\end{array}$ & $\begin{array}{c}h_{1} \\
(\mathrm{kj} / \mathrm{kg})\end{array}$ & $\begin{array}{c}h_{2} \\
(\mathrm{kj} / \mathrm{kg})\end{array}$ & $\begin{array}{c}h_{3} \\
(\mathrm{kj} / \mathrm{kg})\end{array}$ & $\begin{array}{c}h_{4} \\
(\mathrm{kj} / \mathrm{kg})\end{array}$ & $\begin{array}{c}q_{\text {evap }} \\
(\mathrm{kj} / \mathrm{kg})\end{array}$ & $\begin{array}{c}W_{k} \\
(\mathrm{kj} / \mathrm{kg})\end{array}$ & COP \\
\hline 10 & 420 & 439 & 241,6 & 241,6 & 178,4 & 19 & 9,44 \\
20 & 420,2 & 439 & 241,6 & 241,6 & 178,7 & 18,8 & 9,5 \\
30 & 420,3 & 439 & 241,6 & 241,6 & 179.6 & 18,4 & 9,55 \\
40 & 420,3 & 439 & 241,2 & 241,2 & 179,7 & 18,4 & 9,58 \\
50 & 420,5 & 439 & 241,2 & 241,2 & 179,6 & 18,3 & 9,69 \\
60 & 420,5 & 439 & 241,2 & 241,2 & 179,6 & 18,3 & 9,69 \\
70 & 420,5 & 439 & 240,8 & 240,8 & 179,6 & 18,3 & 9,71 \\
80 & 421,6 & 439 & 240,8 & 240,8 & 180,8 & 17,4 & 10,34 \\
90 & 421,6 & 439,1 & 240,6 & 240,6 & 181 & 17,5 & 10,34 \\
100 & 421,8 & 439,2 & 240,6 & 240,6 & 181,2 & 17,4 & 10,41 \\
110 & 421,8 & 439,2 & 238,2 & 238,2 & 181,6 & 17,4 & 10,55 \\
120 & 421,8 & 439,2 & 238,2 & 238,2 & 181,6 & 17,4 & 10,55 \\
\hline Jumlah Total : & & & 2161.4 & 216.6 & 119.35 \\
\hline \multicolumn{7}{l}{ Rata - Rata : }
\end{tabular}

Tabel 3 .

Tekanan dan Temperatur pada Beban Tungku Pemanas $140^{\circ} \mathrm{C}$

\begin{tabular}{llllllll}
\hline $\begin{array}{l}\text { Waktu } \\
(\text { menit })\end{array}$ & $\begin{array}{c}h_{1} \\
(\mathrm{kj} / \mathrm{kg})\end{array}$ & $\begin{array}{c}h_{2} \\
(\mathrm{kj} / \mathrm{kg})\end{array}$ & $\begin{array}{c}h_{3} \\
(\mathrm{kj} / \mathrm{kg})\end{array}$ & $\begin{array}{c}h_{4} \\
(\mathrm{kj} / \mathrm{kg})\end{array}$ & $\begin{array}{c}q_{\text {evap }} \\
(\mathrm{kj} / \mathrm{kg})\end{array}$ & $\begin{array}{c}W_{k} \\
(\mathrm{kj} / \mathrm{kg})\end{array}$ & COP \\
\hline 10 & 420 & 439 & 241,8 & 241,8 & 178,2 & 19,2 & 9,28 \\
20 & 420 & 439 & 241,8 & 241,8 & 178,2 & 19,2 & 9,28 \\
30 & 420 & 439 & 241,8 & 241,8 & 178,2 & 19,2 & 9,28 \\
40 & 420 & 439 & 241,7 & 241,7 & 178,3 & 19,2 & 9,28 \\
50 & 420,1 & 439,3 & 241,7 & 241,7 & 178,4 & 19,2 & 9,29 \\
60 & 420,4 & 439,3 & 241,7 & 241,7 & 178,7 & 18,9 & 9,45 \\
70 & 420,6 & 439,3 & 241 & 241 & 179,6 & 18,7 & 9,67 \\
80 & 420,6 & 439,3 & 241 & 241 & 179,6 & 18,7 & 9,67 \\
90 & 421,4 & 439,3 & 240,5 & 240,5 & 180,9 & 17,9 & 10,10 \\
100 & 421,4 & 439,3 & 240,5 & 240,5 & 180,9 & 17,9 & 10,10 \\
110 & 421,8 & 439,3 & 240 & 240 & 181,8 & 17,5 & 10,38 \\
120 & 421,8 & 439,3 & 240 & 240 & 181,8 & 17,5 & 10,38 \\
\hline Jumlah Total : & & & 2154.6 & 223.1 & 116.16 \\
\hline \multicolumn{7}{l}{ Rata - Rata : }
\end{tabular}

Tabel 4.

Tekanan dan temperatur pada beban tungku pemanas $155^{\circ} \mathrm{C}$

\begin{tabular}{llllllll}
\hline $\begin{array}{l}\text { Waktu } \\
(\text { menit })\end{array}$ & $\begin{array}{c}h_{1} \\
(\mathrm{kj} / \mathrm{kg})\end{array}$ & $\begin{array}{c}h_{2} \\
(\mathrm{kj} / \mathrm{kg})\end{array}$ & $\begin{array}{c}h_{3} \\
(\mathrm{kj} / \mathrm{kg})\end{array}$ & $\begin{array}{c}h_{4} \\
(\mathrm{kj} / \mathrm{kg})\end{array}$ & $\begin{array}{c}q_{\text {evap }} \\
(\mathrm{kj} / \mathrm{kg})\end{array}$ & $\begin{array}{c}W_{k} \\
(\mathrm{kj} / \mathrm{kg})\end{array}$ & COP \\
\hline 10 & 420 & 439,4 & 255 & 255 & 165 & 19 & 8,68 \\
20 & 420 & 439,1 & 255 & 255 & 165,2 & 19 & 8,68 \\
30 & 420,2 & 438,8 & 254 & 254 & 166,2 & 18,6 & 9,04 \\
40 & 420,2 & 438,8 & 250 & 250 & 170,2 & 18,6 & 9,15 \\
50 & 420,2 & 438,8 & 250 & 250 & 170,2 & 18,6 & 9,15 \\
60 & 420,4 & 438,8 & 250 & 250 & 170,4 & 18,4 & 9,26 \\
70 & 420,4 & 438,9 & 246 & 246 & 170,4 & 18,5 & 9,42 \\
80 & 420,8 & 438,8 & 246 & 246 & 170,8 & 18 & 9,71 \\
90 & 420,8 & 438,8 & 246 & 246 & 170,8 & 18 & 9,71 \\
100 & 428 & 438,8 & 246 & 246 & 170,8 & 18 & 9,71 \\
110 & 421,2 & 438,8 & 244 & 244 & 177,2 & 17,6 & 10,06 \\
120 & 421,2 & 438,8 & 244 & 244 & 177,2 & 17,6 & 10,06 \\
\hline \multicolumn{7}{l}{ Jumlah Total : } \\
\hline \multicolumn{7}{l}{ Rata - Rata : }
\end{tabular}

Data dari Tabel 1 sampai 4 kemudian ditampilkan dalam grafik hubungan antara waktu pengujian terhadap nilai COP mesin pendingin pada setiap variasi beban pendinginan.

Dari Gambar 6 dapat dilihat bahwa terjadi penurunan nilai COP dengan semakin tingginya beban pendinginan yang diberikan. Sebaliknya dalam pengaruhnya terhadap waktu pendinginan nilai COP untuk setiap variasi beban pendingan akan semakin bertambah. Nilai COP tertinggi pada penelitian ini didapatkan pada temperatur beban pendinginan $110{ }^{\circ} \mathrm{C}$ sebesar 10,69 dan terendah didapatkan pada temperatur $155^{\circ} \mathrm{C}$ sebesar 9,38.

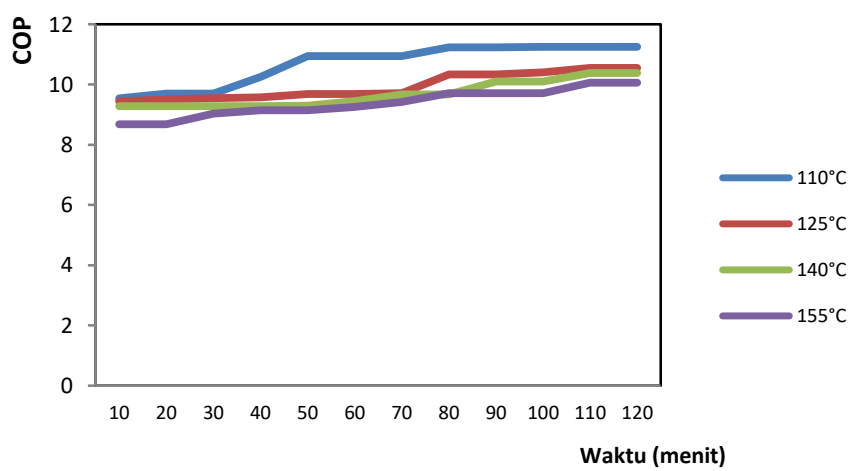

Gambar 6. Grafik Hubungan Waktu Pendinginan Terhadap Nilai Coefficient of Performance (COP) pada Setiap Beban Pendinginan

Penurunan nilai COP akibat semakin bertambahnya beban pendinginan terjadi karena adanya temperatur beban pendinginan yang lebih tinggi memasuki box cooler tempat evaporator berada. Sehingga evaporator sebagai tempat terjadinya penyerapan panas yang dibawa uap dari tungku pemanas harus berkerja lebih banyak untuk menyerap energi panas yang lebih besar. Akibatnya terjadi pengurangan nilai COP disebabkan temperatur yang harus dibuang ke lingkungan oleh mesin pendingin semakin besar. Hal ini juga sama terjadi pada penelitian yang dilakukan oleh Santosa (2017) yang mana menujukkan hasil bahwa semakin besar temperatur yang menjadi beban pendinginan maka nilai COP akan semakin kurang.

Dari grafik dapat dilihat bahwa kalor yang terserap pada evaporator ( $\mathrm{q}_{\mathrm{evap}}$ ) akan bertambah seiring bertambahnya waktu hal ini dikarenkan ruang pendingin (box cooler) semakin lama semakin dingin sehingga kerja yang harus dilakukan kompresor (Wk). Akibat dari berkurangnya kerja yang harus dilakukan kompresor maka nilai COP akan menjadi semakin besar (Kusnandar and Kurniawan 2020).

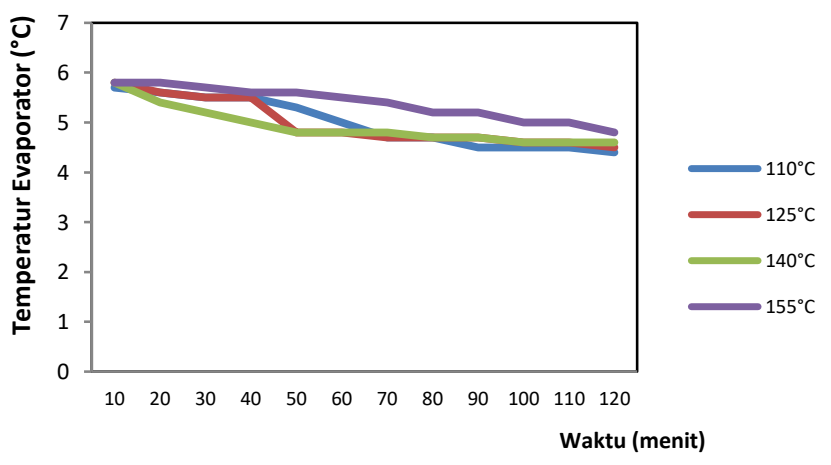

Gambar 7. Grafik hubungan waktu pendinginan terhadap Temperatur Evaporator pada setiap beban pendinginan 
Dari Gambar 7 dapat dilihat bahwa terjadi penurunan temperatur untuk setiap beban pendinginan pada interval waktu yang sama selama 120 menit. Pada evaporator yang khususnya berada pada box cooler mesin distilasi akan terjadi perpindahan panas akibat beban pendinginan yang diberikan oleh tungku pemanas yang selanjutnya dibuang ke lingkungan oleh mesin pendingin. Sehingga semakin besar beban pendinginan pada sistem maka semakin besar pula kalor yang harus dibuang ke lingkungan oleh mesin pendingin. Dari gambar diatas juga dapat dilihat bahwa beban pada pendinginan terbesar $\left(155^{\circ} \mathrm{C}\right)$ dengan nilai COP awal sebesar 8,68 membutuhkan waktu selama 120 menit untuk meningkatkan nilai COP menjadi 10,06 yang artinya mesin membutuhkan waktu yang lama untuk menurunkan temperatur pada evaporator dibanding beban pendingin lainnya.

Dari hasil penelitian dengan memberikan temperatur pemanasan hingga mencapai $155{ }^{\circ} \mathrm{C}$ pada tungku penguapan bahan hasil fermentasi menjadi alkohol masih masih mampu untuk mesin pendingin berkerja dengan baik. Dimana nilai COP mesin pendingin yang cendrung selalu bertambah seiring lama waktu pengujian sehingga kapasitas pendinginan yang dimiliki oleh mesin pendingin masih tepat untuk mesin distilasi.

\section{SIMPULAN DAN SARAN}

Berdasarkan hasil pembahasan dan analisa yang telah dipaparkan mengenai pengaruh beban pendinginan terhadap nilai Coefficient of Performance mesin pendingin pada mesin distilasi dapat disimpulkan bahwa semakin tinggi beban pendinginan maka semakin kecil nilai COP mesin pendingin yang artinya semakin besar temperatur di dalam box cooler yang harus dibuang mesin pendingin ke lingkungan. Dimana, beban pendinginan $155^{\circ} \mathrm{C}$ merupakan beban pendinginan tertinggi. Selain itu, dalam pengaruhnya terhadap waktu pengujian nilai COP untuk setiap variasi beban pendingan akan semakin bertambah. Nilai COP tertinggi pada penelitian ini didapatkan pada temperatur beban pendinginan $110{ }^{\circ} \mathrm{C}$. Selanjutnya, kerja kompresor sangat berpengaruh terhadap efek refrigerasi atau COP yang ditimbulkan. Karena semakin besar beban pendinginan maka kerja kompresor juga semakin meningkat.

\section{DAFTAR RUJUKAN}

Anwar, Khairil. 2010. "Efek Beban Pendingin Terhadap Performa Sistem Mesin Pendingin." Jurnal SMARTek 8(3):203.

BPPT. 2014. Pengembangan Energi Untuk Mendukung Program Substitusi BBM. Vol. 1.

Chen, Lingen, Chih Wu, and Fengrui Sun. 1998. "Cooling Load versus COP Characteristics for an Irreversible Air Refrigeration Cycle." Energy Conversion and Management 39(1-2):117-25. doi: 10.1016/so1968904(96)00119-7.

Emmaputri, Fathia Salsabila, Sarifah Nurjanah, Efri
Mardawati, M. Ade Moetangad Kramadibrata, Mimin Muhaemin, Wahyu Daradjat, Handarto Handarto, and Totok Herwanto. 2019. "Kajian Proses Distilasi Fraksinasi Biodiesel Kemiri Sunan (Reutealis Trisperma)." Jurnal Teknotan 12(2):29. doi: 10.24198/jt.vol12n2.5.

Ilminnafik, Nasrul, and Digdo Listyadi. 2013. "Pengaruh Variasi Beban Pendingin Terhadap Prestasi Kerja Mesin Pendingin Dengan Refrigeran R12 Dan Lpg." Rotor $6(1): 30-34-34$.

Kusnandar, Kusnandar, and Yudhy Kurniawan. 2020. "Perbandingan COP AC Split Kapasitas 1 PK Menggunakan Refrigerant R410a Dan R32 Dengan Variasi Kecepatan Fan Evaporator ." TURBULEN Jurnal Teknik Mesin 2(2):50. doi: 10.36767/turbulen.v2i2.553.

Mainil, Rahmat Iman, and Afdhal Kurniawan Aziz. 2015. "Penggunaan Modul Thermoelectric Sebagai Elemen Pendingin Box cooler." Rekayasa Dan Aplikasi Teknik Mesin Di Industri Kampus ITENAS 1(December):44-49.

Marjoni, Mhd. Riza. 2014. "Pemurnian Etanol Hasil Fermentasi Kulit Umbi Singkong (Manihot Utilissima Pohl) Dari Limbah Industri Kerupuk Sanjai Di Kota Bukittinggi Berdasarkan Suhu Dan Waktu Distilasi." Pharmaciana 4(2):193-200. doi: 10.12928/pharmaciana.v4i2.1578.

Metty, Komang, Trisna Negara, and Hendra Wijaksana. 2012. "Analisa Performansi Sistem Pendingin Ruangan Dan Efisiensi Energi Listrik padaSistem Water Chiller Dengan Penerapan Metode Cooled Energy Storage.” Jurnal Energi Dan Manufaktur 4(1):4-11.

Mursito, Judhid Adi, I. Gusti Ketut Sukadana, and I. Gusti Ngurah Putu Tenaya. 2017. "Perancangan Dan Pengujian Alat Distilasi Minyak Dari Limbah Sampah Plastik." Jurnal Ilmiah Teknik Desain Mekanika 6(4):311-17.

Nikhil Babu, P., D. Mohankumar, P. Manoj Kumar, M. Makeshkumar, M. Gokulnath, K. Gurubalaji, G. Harrish, and M. Ashok. 2021. "Energy Efficient Refrigeration System with Simultaneous Heating and Cooling." Pp. 8188-94 in Materials Today: Proceedings. Vol. 45.

Ramadan, Haris. 2018. "Uji Prestasi Refrigeran R22 Pada Mesin Pendingin Kompresi Uap Dengan Metode Pengujian Aktual Dan Simulasi." Konversi Energi Dan Manufaktur UNJ 5(2):74-81.

Rubianto, Budi, Rochmad Winarso, and Rianto Wibowo. 2018. "Rancang Bangun Kondensor Pada Destilator Bioetanol Kapasitas 5 Liter/Jam Dengan Skala Umkm.” Jurnal Crankshaft 1(1). doi: 10.24176/crankshaft.v1i1.2587.

Santosa, Tito Hadji Agung, Muhammad Nadjib, Thoharuddin, and Muhammad Akhid Riza. 2017. "Efek Variasi Beban Pendinginan Terhadap Coefficient Of Performance (COP) Alat Uji Pengukuran Koefisien Evaporasi Menggunakan Refrigeran R-134A.” Semesta Teknika 20(2):193-203.

Seftian, Deky, Ferdinand Antonius, and M. Faizal. 2012. "Pembuatan Etanol Dari Kulit Pisang Menggunakan Metode Hidrolisis Enzimatik Dan Fermentasi." Jurnal Teknik Kimia 18(1):10-16.

Siagian, S. 2017. "Perhitungan Beban Pendingin Pada Cold Storage Untuk Penyimpanan Ikan Tuna Pada Pt . X.” Bina Teknika 13(1):139-49. 